\title{
Temperature and Nutrient Limitations Decrease Transfer of Conjugative IncP-1 Plasmid pKJK5 to Wild Escherichia coli Strains
}

\section{OPEN ACCESS}

Edited by: Jorge Andres Olivares Pacheco, Pontificia Universidad Católica de Valparaíso, Chile

Reviewed by: Isabel Henriques, University of Aveiro, Portugal Carolina Yáñez,

Pontificia Universidad Católica de Valparaíso, Chile

${ }^{*}$ Correspondence:

Mark C. M. van Loosdrecht M.C.M.vanLoosdrecht@tudelft.nl

tThese authors have contributed equally to this work and share first authorship

Specialty section: This article was submitted to Antimicrobials, Resistance and Chemotherapy,

a section of the journal Frontiers in Microbiology

Received: 20 January 2021 Accepted: 23 June 2021 Published: 19 July 2021

Citation:

Pallares-Vega R, Macedo G, Brouwer MSM, Hernandez Leal $L$, van der Maas $P$

van Loosdrecht MCM,

Weissbrodt DG, Heederik D, Mevius D and Schmitt H (2021) Temperature and Nutrient Limitations Decrease Transfer of Conjugative IncP-1 Plasmid pKJK5 to Wild

Escherichia coli Strains.

Front. Microbiol. 12:656250. doi: 10.3389/fmicb.2021.656250

\author{
Rebeca Pallares-Vega ${ }^{1,2+}$, Gonçalo Macedo ${ }^{1,3+}$, Michael S. M. Brouwer, \\ Lucia Hernandez Leal' ${ }^{1}$, Peter van der Maas ${ }^{5}$, Mark C. M. van Loosdrecht ${ }^{2 *}$, \\ David G. Weissbrodt' ${ }^{2}$, Dick Heederik ${ }^{6}$, Dik Mevius ${ }^{3,4}$ and Heike Schmitt1,3,6
}

1 Wetsus, European Centre of Excellence for Sustainable Water Technology, Leeuwarden, Netherlands, ${ }^{2}$ Department Biotechnology, Delft University of Technology, Delft, Netherlands, ${ }^{3}$ Department of Infectious Diseases and Immunology, Faculty of Veterinary Medicine, Utrecht University, Utrecht, Netherlands, ${ }^{4}$ Department of Bacteriology and Epidemiology, Wageningen Bioveterinary Research, Lelystad, Netherlands, ${ }^{5}$ Van Hall Larenstein, University of Applied Sciences, Leeuwarden, Netherlands, ${ }^{6}$ Institute for Risk Assessment Sciences, Utrecht University, Utrecht, Netherlands

Plasmid-mediated dissemination of antibiotic resistance among fecal Enterobacteriaceae in natural ecosystems may contribute to the persistence of antibiotic resistance genes in anthropogenically impacted environments. Plasmid transfer frequencies measured under laboratory conditions might lead to overestimation of plasmid transfer potential in natural ecosystems. This study assessed differences in the conjugative transfer of an IncP-1 (pKJK5) plasmid to three natural Escherichia coli strains carrying extended-spectrum beta-lactamases, by filter mating. Matings were performed under optimal laboratory conditions (rich LB medium and $37^{\circ} \mathrm{C}$ ) and environmentally relevant temperatures $\left(25,15\right.$ and $\left.9^{\circ} \mathrm{C}\right)$ or nutrient regimes mimicking environmental conditions and limitations (synthetic wastewater and soil extract). Under optimal nutrient conditions and temperature, two recipients yielded high transfer frequencies $\left(5 \times 10^{-1}\right)$ while the conjugation frequency of the third strain was 1000 -fold lower. Decreasing mating temperatures to psychrophilic ranges led to lower transfer frequencies, albeit all three strains conjugated under all the tested temperatures. Low nutritive media caused significant decreases in transconjugants ( -3 logs for synthetic wastewater; -6 logs for soil extract), where only one of the strains was able to produce detectable transconjugants. Collectively, this study highlights that despite less-thanoptimal conditions, fecal organisms may transfer plasmids in the environment, but the transfer of pKJK5 between microorganisms is limited mainly by low nutrient conditions.

Keywords: horizontal gene transfer, antimicrobial resistance, synthetic wastewater, soil extract agar, environmental conditions, AMR

\section{INTRODUCTION}

Antimicrobial resistance (AMR) is considered as one of the most significant challenges to global public health (O'Neill, 2016). The spread of antimicrobial resistance genes (ARGs) via horizontal gene transfer (HGT) between bacteria is a growing concern because it facilitates the dissemination of resistance across a wide variety of microorganisms. Understanding the dynamics of plasmid dissemination in the environment is fundamental to contain and mitigate the AMR challenge. 
Horizontal gene transfer (HGT) is an effective ecological trait that shapes bacterial evolution (Ochman et al., 2000). Conjugative plasmids are relevant vectors for HGT (Smillie et al., 2010) and dissemination of AMR (Carattoli, 2013). Gut bacteria from both animal and human origin comprise an important source of AMR-conjugative plasmids (Hu et al., 2013; Ceccarelli et al., 2019). Gut bacteria are released into the environment through manure application to agricultural soils and wastewater discharges, ultimately resulting in the introduction of their ARGs, and plasmids in the environment. Despite having limited survivability, once introduced in the environment, gut bacteria might be able to transfer their AMR determinants to the natural bacterial community. Escherichia coli is widely accepted as primary indicator of fecal contamination. Although most E. coli strains cause only mild infections, their presence is indicative of the potential presence of other more pathogenic organisms which may be relevant for human health.

Monitoring of environmental HGT remains challenging mainly due to cultivation bias [only $1 \%$ of indigenous bacteria are estimated to be cultivable (Amann et al., 1995)]. Fluorescently labeled strains and plasmids comprise a promising methodology to study horizontal gene transfer in complex environments by culture independent methods (Sørensen et al., 2005). Due to donor-recipient incompatibilities and detection limits of the methodology, the experimental design often require a compromise to guarantee the detection of transconjugants (Sørensen et al., 2005; Pinilla-Redondo et al., 2018). As a result, studies addressing environmental dissemination of AMR plasmids usually apply conditions that are optimal for bacterial transmission, namely high bacterial densities, optimal growth temperatures, and/or high nutrient availability (Bellanger et al., 2014a; Jacquiod et al., 2017). Although being relevant for specific scenarios such as mesophilic anaerobic digesters, greenhouses or wastewater in low latitude countries (Al Qarni et al., 2016; Fan et al., 2019), these settings do not reflect the usual average conditions of manured soils, water bodies and wastewater (Abis and Mara, 2006; Barrios-Hernández et al., 2020; Osińska et al., 2020). Such discrepancies in the experimental design might lead to an overestimation of plasmid transfer frequencies and dissemination potential in the environment. Therefore, better insights into how environmental parameters affect plasmid transfer are needed.

The aim of this study was to evaluate in vitro the role of environmental factors that could potentially hamper conjugative plasmid transfer from gut bacteria once discharged into the environment. A conjugative broad host range IncP-1plasmid (pKJK5) was used as vector. Most importantly, IncP-1 plasmids have comparatively high conjugation rates and thus allow for analysis of conjugation frequency also under suboptimal conjugation conditions. IncP-1 plasmids often carry clinically relevant ARGs (Rozwandowicz et al., 2018), are abundant in (waste)water (Pallares-Vega et al., 2021), manure (Binh et al., 2008), and soil environments (Shintani et al., 2020) and can potentially disseminate among a wide diversity of phylogenetic groups (Popowska and Krawczyk-Balska, 2013). Furthermore, IncP-1 plasmids (i.e., RP4, pB10 and pKJK5) comprise the predominant plasmids in studies addressing transfer events in environmental settings (Inoue et al., 2005; Bellanger et al., 2014b; Klümper et al., 2015; Li et al., 2018). Solid-surface filter matings were conducted to study HGT between Escherichia coli strains (as both donor and recipients, with animal E. coli strains harboring extended spectrum beta-lactamase resistance genes on known plasmid types as recipients representative of $E$. coli introduced with animal manure). The transfer was evaluated under different (i) donor-to-recipient cell proportions, (ii) mating temperatures, or (iii) nutritional compositions. The criteria to select the used conditions was based on the presumable main abiotic challenges that gut bacteria face when discharged into the environment, namely nutrient limitations and close-to psychrophilic conditions. The donor-to-recipient cell proportions were tested to assess the limit of the system while aiming for a natural proportion of donor and recipient cells in the mating. By using the same species and a broad-host-range plasmid, potential host-vector and interspecies incompatibilities were discarded as factors. E. coli was chosen as a model system for bacteria of public health relevance that can potentially move between anthropogenic related and natural environments, and it was hypothesized that lower temperatures and lower nutrient concentrations would limit plasmid transfer.

\section{MATERIALS AND METHODS}

\section{Selection and Characterization of Strains and Plasmids}

Three extended-spectrum beta-lactamase (ESBL) carrying E. coli strains $(09.54,38.27$, and 39.62) isolated from fecal samples of calves or poultry were used as recipients during the mating experiments (Table 1). These strains were part of a database from the Dutch national veterinarian institute (Wageningen Bioveterinary Research, WBVR), studying the prevalence of ESBLs in plasmids. The strains qualify for this work because of their species, diverse plasmid content, and because they had been sequenced under the scope of WBVR projects. A genetically engineered $E$. coli strain previously described by Klümper et al. (2015) was selected as donor for the broad-host-range plasmid of the incompatibility group IncP-1. The donor strain (E. coli $\mathrm{K}-12$ MG1655:lacI ${ }^{\mathrm{q}}-p L p p-m$ Cherry- $K \mathrm{~m}^{\mathrm{R}}$ ) is commonly used in duallabeling fluorescence reporter-gene approaches coupled with fluorescence-activated cell sorting (Pinilla-Redondo et al., 2018) due to the conditionally expressible green fluorescent proteins (GFP) in its IncP-1 plasmid (pKJK5). The IncP-1 plasmid carries a kanamycin resistance determinant and lacI $^{\mathrm{q}}$ repressible promoter upstream the gfpmut3 gene (Sengeløv et al., 2001; Bahl et al., 2007; Klümper et al., 2015).

In order to fully characterize the used strains, wholegenome sequencing using paired-end Illumina was performed, as previously described by Rozwandowicz et al. (2020). The annotation of the sequences was performed with Prokka version 1.12 (Seemann, 2014) and the corresponding sequence type a was conducted with the Multi Locus Sequence Typing online tool MLST 2.0 (Larsen et al., 2012), using the two available schemes (Wirth et al., 2006; Jaureguy et al., 2008). For typing the donor strain and relate the natural recipient strains to 
TABLE 1 | Bacterial strains of $E$. coli used as donor and recipient of broad-host-range IncP-1 plasmid, and their characteristics.

\begin{tabular}{|c|c|c|c|c|c|c|}
\hline Agent & ST & Role & Origin & Resistance profile & Plasmids & Source \\
\hline E. coli MG1655:lacla-pLpp-mCherry-Km & ST10/ST262 & Donor & $\begin{array}{l}\text { Laboratory } \\
\text { strain }\end{array}$ & 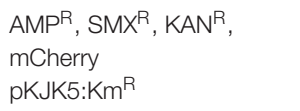 & 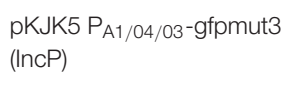 & $\begin{array}{l}\text { Klümper et al. } \\
\text { (2015) }\end{array}$ \\
\hline E. coli 09.54 & ST21/ST481 & Recipient & Veal calf & AMP $^{R}$, CTX $^{R}$, SMX $^{R}$, TET $^{R}$ & IncK & This study \\
\hline E. coli 38.27 & ST10/ST2 & Recipient & Poultry & AMP $^{R}$, CTX $^{R}, S^{\prime} X^{R}$, TET $^{R}$ & IncFI, IncH1, Incl1, p0111 & This study \\
\hline E. coli 39.62 & ST101/ST88 & Recipient & Poultry & $\mathrm{AMP}^{\mathrm{R}}, \mathrm{CTX}^{\mathrm{R}}, \mathrm{SMX}^{\mathrm{R}}, \mathrm{TET}^{\mathrm{R}}$ & $\begin{array}{l}\text { IncFIB/FI| } \\
\text { IncK }\end{array}$ & This study \\
\hline
\end{tabular}

ST, Sequence type.

the donor, a reference sequence of E. coli MG1665 (accession number: NC_000913.3) from GenBank was used. In addition, the existence of plasmid replicons within the strains was analyzed with PlasmidFinder (Carattoli et al., 2014) applying an identity cut-off equal or greater than 98\%. The annotated sequences are deposited in GenBank, BioProject PRJNA661180 under the accession no. JADPVO000000000 (09.54), JADPVP000000000 (38.27) and JADPVQ000000000 (39.62) A core and accessory genome analysis of the donor and recipient strains was conducted with Roary version 13.0 (Page et al., 2015) in Galaxy version $21.01^{1}$. A maximum likelihood tree based on nucleotide sequence was built with FastTree version 2.1.10 (Price et al., 2010) in Galaxy and graphic visualization of the core and accessory genome was achieved with Phandango (Hadfield et al., 2018).

To identify suitable selective conditions for the identification of transconjugants, the antimicrobial susceptibility profile for each strain was determined by disc diffusion test, according to EUCAST guidelines (EUCAST Disk Diffusion Method for Antimicrobial Susceptibility Testing - version 6.0; available at https://www.eucast.org/). The results were interpreted based on the EUCAST-defined Breakpoints tables for interpretation of MICs and zone diameters (version 8.0) and are summarized in Table 1 in Supplementary Information. Figure 1 displays this study's schematic of the experimental design and procedure.

\section{Culture Media and Growth Curves}

Luria-Bertani (LB), synthetic wastewater (SWW), and soil extract (SE) were used as culture media for the filter matings. Pure bacterial cultures were prepared and maintained in LB broth or plates (tryptone $10 \mathrm{~g} \mathrm{~L}^{-1}$, yeast extract $5 \mathrm{~g} \mathrm{~L}^{-1}$, sodium chloride $5 \mathrm{~g} \mathrm{~L}^{-1}$, and agar $15 \mathrm{~g} \mathrm{~L}^{-1}$ ) prior to the experiments, and for the selection of donor, recipients, and transconjugants after the matings, the LB plates were enriched with kanamycin (100 $\mu \mathrm{g} \mathrm{mL}^{-1}$; Sigma Aldrich), tetracycline (16 $\mathrm{g} \mathrm{mL}^{-1}$; Sigma Aldrich), and both kanamycin and tetracycline (100 and $16 \mu \mathrm{g}$ $\left.\mathrm{mL}^{-1}\right)$, respectively.

The SWW aimed to mimic the average conditions and nutrient proportions of conventional domestic wastewater. The composition was based on that of Boeije et al. (1999), and ISO 11733 guideline, and adjusted to a theoretical COD:N:P concentration and molar ratio close to that of Dutch wastewater (100:9.1:1.4, Supplementary information Table 2). The SWW solution contained of $0.07 \mathrm{~g} \mathrm{~L}^{-1}$ urea, $0.011 \mathrm{~g} \mathrm{~L}^{-1} \mathrm{NH}_{4} \mathrm{Cl}, 0.015 \mathrm{~g}$ $\mathrm{L}^{-1}$ peptone $\mathrm{P}$ (Oxoid, United Kingdom), $0.015 \mathrm{~g} \mathrm{~L}^{-1}$ Lab Lemco

${ }^{1}$ https://usegalaxy.eu/
(Oxoid, United Kingdom), $0.05 \mathrm{~g} \mathrm{~L}^{-1}$ starch, $0.04 \mathrm{~g} \mathrm{~L}^{-1}$ glycerol that was sterilized by autoclaving. After sterilization, the mix was completed with $0.25 \mathrm{~g} \mathrm{~L}^{-1}$ sodium acetate, $0.12 \mathrm{~g} \mathrm{~L}^{-1}$ skimmed milk powder (Sigma Aldrich, NL), $0.05 \mathrm{~g} \mathrm{~L}^{-1}$ glucose, $0.025 \mathrm{~g} \mathrm{~L}^{-1}$ $\mathrm{FeSO}_{4}, 0.005 \mathrm{CaCl}_{2} \mathrm{~g} \mathrm{~L}^{-1}, 0.025 \mathrm{~g} \mathrm{~L}^{-1} \mathrm{NaHCO}_{3}$ and $0.02 \mathrm{~g} \mathrm{~L}^{-1}$ $\mathrm{MgHPO}_{4} \cdot 3 \mathrm{H}_{2} \mathrm{O}, 0.016 \mathrm{~g} \mathrm{~L}^{-1} \mathrm{~L} \mathrm{~K}_{3} \mathrm{PO}_{4} \cdot \mathrm{H}_{2} \mathrm{O}$ (unless indicated otherwise, the components were purchased at VWR, NL). These solutions were separately autoclaved, or filter sterilized prior to their aseptic addition to the final solution. SWW media was finally supplemented with the addition of $0.1 \%(\mathrm{v} / \mathrm{v})$ of trace metal solution which contained $0.280 \mathrm{~g} \mathrm{~L}^{-1} \mathrm{NaEDTA}, 0.180 \mathrm{~g}$ $\mathrm{L}^{-1} \mathrm{ZnCl}_{2}, 1.144 \mathrm{~g} \mathrm{~L}^{-1} \mathrm{H}_{3} \mathrm{BO}_{3}, 0.025 \mathrm{~g} \mathrm{~L}^{-1} \mathrm{CoCl}_{2} \cdot 6 \mathrm{H}_{2} \mathrm{O}$, $0.589 \mathrm{~g} \mathrm{~L}^{-1} \mathrm{MnCl}_{2} \cdot 2 \mathrm{H}_{2} \mathrm{O}, 0.120 \mathrm{~g} \mathrm{~L}^{-1} \mathrm{CuCl}_{2} \cdot 2 \mathrm{H}_{2} \mathrm{O}, 0.068 \mathrm{~g}$ $\mathrm{L}^{-1} \mathrm{NiCl}_{2} \cdot 6 \mathrm{H}_{2} \mathrm{O}, 0.025 \mathrm{~g} \mathrm{~L}^{-1} \mathrm{Na}_{2} \mathrm{MoO} 4 \cdot 5 \mathrm{H}_{2} \mathrm{O}$, and $0.212 \mathrm{~g} \mathrm{~L}^{-1}$ $\mathrm{KCr}\left(\mathrm{SO}_{4}\right)_{2} \cdot 12 \mathrm{H}_{2} \mathrm{O}$. The $\mathrm{pH}$ was adjusted to $6.8 \pm 0.1$ with $\mathrm{NaOH}$ $1 \mathrm{M}$ to match the values found in wastewater [6.5 - 8.5 (Prot et al., 2020)]. When needed, agar $\left(15 \mathrm{~g} \mathrm{~L}^{-1}\right)$ was added for solid media preparation.

Soil samples for SE medium preparation were collected in the late fall of 2019, from a local dairy farm (Friesland, Netherlands) that uses the field for pasture (grassland) and had not been recently subjected to manure application. In total, $7 \mathrm{~kg}$ of sandy loam soil were collected from the field and homogenized. The collected soil was air-dried for 3 days and stored in $500 \mathrm{~g}$ zip bags at $4^{\circ} \mathrm{C}$ until being used. The SE media was prepared as described by Musovic et al. (2010). Briefly, $500 \mathrm{~g}$ of dried soil was mixed with $500 \mathrm{~mL}$ of demineralized water. Then, the mixture was shaken horizontally, for $3 \mathrm{~h}$, and left for passive settling of the particles, for $5 \mathrm{~h}$. After the $5 \mathrm{~h}$, the supernatant was pipetted and autoclaved (for $15 \mathrm{~min}$, at $121^{\circ} \mathrm{C}$ ) and stored at $4^{\circ} \mathrm{C}$, up to one month. The $\mathrm{pH}$ values were not adjusted and were kept at its original values $(5.0-5.3)$, and no buffer solutions were used to maintain the $\mathrm{pH}$ in the different culture media because they could introduce potential nutrients (e.g., phosphate). When needed, agar was added as aforementioned.

The general chemical compositions of the LB, SWW, and SE media were determined by ion chromatography (IC), and inductively coupled plasma (ICP-OES). The determination of the chemical oxygen demand (COD), and the total nitrogen (TN) was achieved with commercially available kits (LCK 514 and LCK 338; Hach). The determination of the total organic carbon (TOC) was achieved with Shimadzu TOC-L $\mathrm{CPH}_{\mathrm{C}}$ analyzer. The composition of the different media used is displayed in Table 2.

To quantify the effect of the temperature change in the growth, an inoculum volume of $0.2 \%$ (final volume) of overnight culture of each strain was transferred to fresh LB, and incubated 

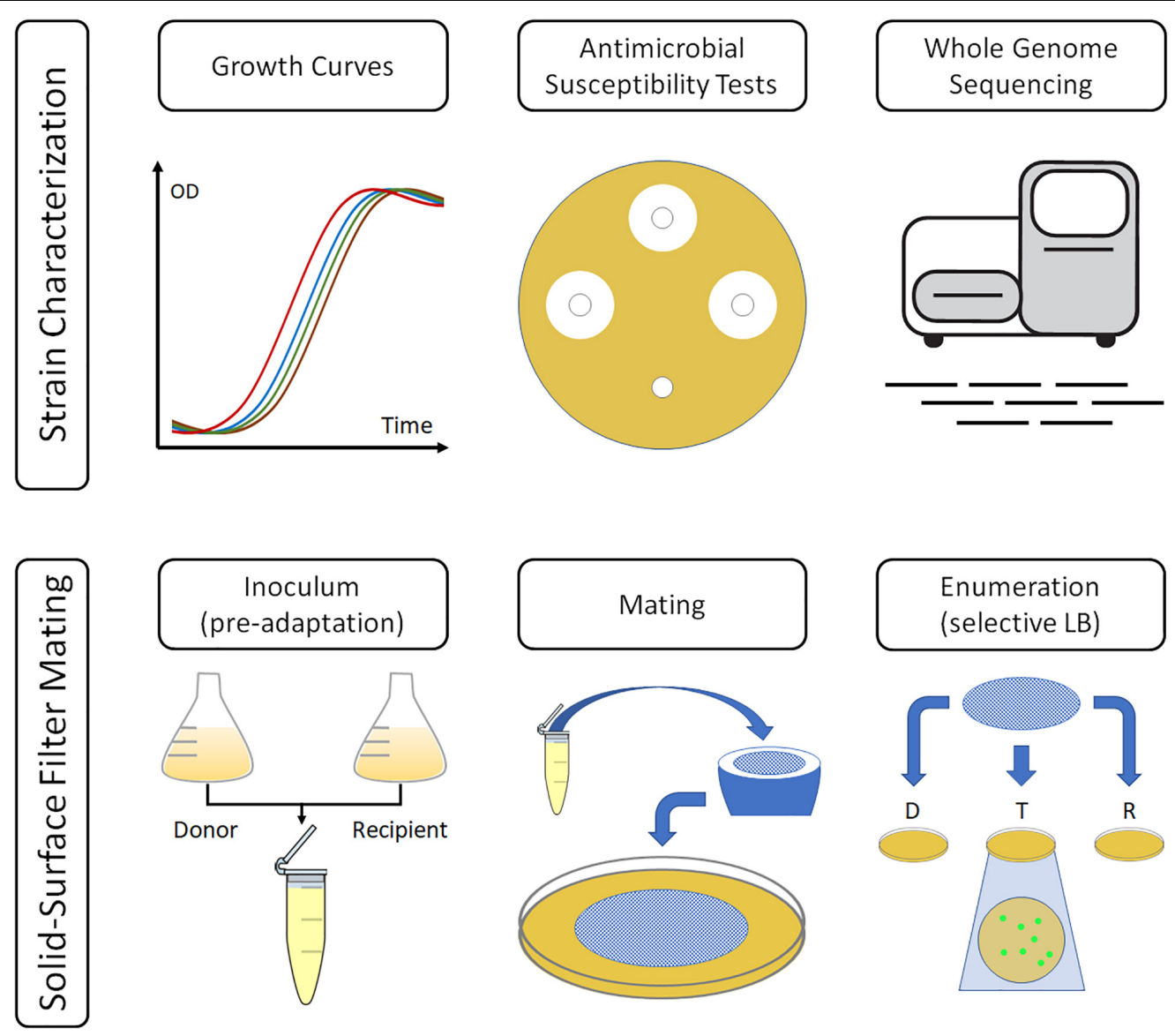

FIGURE 1 | Overview of the procedure to quantify transconjugants. Donors and recipients were grown separately before being mixed, filtered, and incubated for $2 \mathrm{~h}$, at different temperatures or at different media. In the end, bacteria were recovered, and enumerated, in LB containing antibiotic combinations specific for donors, recipients, or transconjugants.

at $9,15,25$, or $37^{\circ} \mathrm{C}$. The Pathogen Modeling Program (PMP) online model (available at: https://pmp.errc.ars.usda. gov/default.aspx) was used to predict the incubation time range to measure bacterial density. To determine the effect of the nutrient composition, inoculums of $0.2 \%$ (final volume) overnight culture of each strain were transferred to SWW or SE media, and monitored up to three days. The optical density, at $600 \mathrm{~nm}\left(\mathrm{OD}_{600}\right)$, was measured in a UV-Vis Spectrophotometer (Shimadzu Corp). Colony forming units (CFUs) were determined after preparing 10-fold serial dilutions with saline solution $(\mathrm{NaCl}$; $0.85 \%$ ), plating in $\mathrm{LB}$ agar, and incubating at $37^{\circ} \mathrm{C}$, overnight. Measurements were performed in biological triplicates.

\section{Solid Surface Filter Matings: Standard Conditions}

Conjugation is a process that requires cell proximity and stable spatial conditions during the mating time (ca 3-5 min). Although these conditions can occur in the liquid phase, they are more likely in "surface-like" configurations (Zhong et al., 2010) occurring in soil grains, sludge flocs or biofilms. Bearing this in mind, filter mating was chosen to study the plasmid transfer.
The conjugation assays were performed by mixing $150 \mu \mathrm{L}$ of fresh culture of the donor and recipient, and vacuum filtered through mixed-cellulose ester filters (0.45 $\mu \mathrm{m}$; Millipore) in a Millipore filtration system. Prior to mixing, the cultures were grown for approximately $3 \mathrm{~h}$ in $\mathrm{LB}$ at $37^{\circ} \mathrm{C}$ to achieve

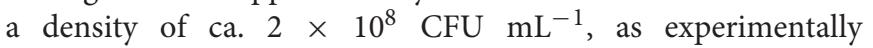
defined by the growth curves. After filtration, the mixed cultures were transferred to plates containing LB and cells were then incubated at $37^{\circ} \mathrm{C}$. Following the incubation period, the cells were detached from the filter by vortexing in $1 \mathrm{~mL}$ of sterile LB broth, for $5 \mathrm{~min}$. Subsequently, serial decimal dilutions were prepared in sterile saline solution, and $100 \mu \mathrm{L}$ was spread on LB plates containing kanamycin (donors), tetracycline (recipients) and a combination of both (transconjugants). The results were observed after a 24-h incubation period (total counts), at $37^{\circ} \mathrm{C}$, and another 24 -h incubation period (colored colonies), at $4^{\circ} \mathrm{C}$. The incubation at $4^{\circ} \mathrm{C}$ was performed to enhance the visualization of the GFP protein (Scott et al., 2006) and to count the green colonies, the plates were observed in a blue-light transilluminator (Safe Imager 2.0; Invitrogen). To confirm the validity of each assay, matings with only the donor or the recipient were also 
TABLE 2 | Media composition of the culture media used in the matings with either Luria-Bertani (LB), synthetic wastewater (SWW) or soil extract (SE) medium.

\begin{tabular}{|c|c|c|c|c|c|c|}
\hline \multirow{2}{*}{$\begin{array}{l}\text { (mg L-1) } \\
\text { Compound }\end{array}$} & \multicolumn{2}{|c|}{ LB } & \multicolumn{2}{|c|}{ swW } & \multicolumn{2}{|c|}{ SE } \\
\hline & Mean & SD & Mean & SD & Mean & SD \\
\hline TOC & 6,820 & 80 & 219 & 1.0 & 45 & - \\
\hline COD & 21,450 & 2,450 & 529 & 37 & 173 & 1 \\
\hline $\mathrm{TN}$ & 2,050 & 20 & 48 & 2 & 7 & 0.4 \\
\hline $\mathrm{TP}$ & 151 & 1 & 7.2 & 0.2 & 4 & 0.0 \\
\hline $\mathrm{Ca}^{2+}$ & 9 & 1 & 3.6 & 0.0 & 104 & 1 \\
\hline $\mathrm{K}^{+}$ & 272 & 2 & 11.5 & 0.1 & 21 & 9.9 \\
\hline $\mathrm{Mg}^{2+}$ & 7 & 0.1 & 37.6 & 0.1 & 5 & 0.6 \\
\hline $\mathrm{Fe}^{2+/ 3+}$ & 0 & 0.0 & 4.5 & 0.0 & $<0.05$ & - \\
\hline S & 127 & 0 & 38 & 1 & 67 & 2 \\
\hline $\mathrm{NH}_{4}+$ & 60 & 0 & 6.2 & 0.0 & $<0.10$ & - \\
\hline $\mathrm{NO}_{3}{ }^{-}$ & 4 & 0.0 & $<0.10$ & - & 10 & 0.0 \\
\hline $\mathrm{PO}_{4}{ }^{3-}$ & 259 & 1 & $>20$ & - & 12 & 0.0 \\
\hline $\mathrm{SO}_{4}{ }^{2-}$ & 96 & 9 & 11 & 0 & 191 & 7 \\
\hline
\end{tabular}

Total organic carbon (TOC), chemical oxygen demand (COD), total nitrogen (TN), total phosphorus (TP)

performed. Each mating was performed in biological triplicates on alternative days.

\section{Solid Surface Filter Matings: Modified Conditions}

When different proportions of donor-to-recipient ratios (D/R) were tested, the donor cultures harvested until $10^{8} \mathrm{CFU} \mathrm{\textrm {mL } ^ { - 1 }}$ were serially diluted (10 and 100-fold) in LB and $150 \mu \mathrm{L}$ was mixed with $150 \mu \mathrm{L}$ recipient culture to reach the corresponding ratios $\mathrm{D} / \mathrm{R}$ of $1: 10$ and $1: 100$. A total volume of $200 \mu \mathrm{L}$ of the mixtures were then filtered, and the mating and incubation were performed as aforementioned. The approximate cell density in the filters was $8.9 \times 10^{6} \mathrm{CFU} \mathrm{\textrm {cm } ^ { - 2 }}$. The effect of temperature in transfer frequency was assessed by following the standard condition procedure, but incubating the filters at 25,15 and $9^{\circ} \mathrm{C}$ in LB plates pre-conditioned to the corresponding temperatures. To assess the influence of nutrient availability in the transfer frequency, matings conducted in SWW and SE media were compared to standard nutrient-rich media LB. For SWW matings, donor and recipient cell cultures were pre-adapted to low nutrient conditions by growing them in SWW media (1\% overnight inoculum) for approximately $4 \mathrm{~h}$ with $180 \mathrm{rpm}$ agitation until a cell density of ca. $2 \times 10^{8} \mathrm{CFU} \mathrm{\textrm {mL } ^ { - 1 }}$ was achieved. Then, cell cultures were mixed and filtered as aforementioned in the standard conditions, and filters were placed in SWW agar plates. Plates were incubated at $37^{\circ} \mathrm{C}$ for 2 h. For SE matings, no pre-growth from donor nor recipients could be obtained in SE broth, as indicated by the corresponding growth curves (data not shown). Instead, late log phase LB cultures of both donor and recipients ca. $2 \times 10^{8}$ were centrifuged and washed twice in saline solution, and the pellet was finally resuspended in $10 \mathrm{~mL}$ of SE broth and incubated overnight at $37^{\circ} \mathrm{C}$. Before incubation, an aliquot of the resuspended cells was serially diluted in saline solution, plated in LB and incubated overnight at $37^{\circ} \mathrm{C}$. Following the incubation and based on the cell counts of the suspensions, the cell density of both donor and recipient SE cultures were adjusted to approximately $2 \times$

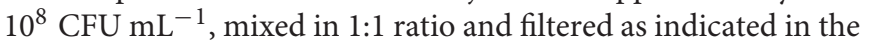
standard procedure. Filters were then placed on SE media and incubated at $37^{\circ} \mathrm{C}$ for $24 \mathrm{~h}$. In all modified filter matings, cell recovery and subsequent plating were performed as mentioned in the standard conditions.

\section{Genetic Characterization of Donor, Recipient, and Transconjugants}

To confirm the strain identity (donor, recipient, and transconjugants), five to ten isolates per mating were collected randomly from each of the media containing the antibiotics, and PCR was performed on the crude cell extracts. Reactions targeting the 16S rRNA gene, mCherry, and gfpmut3 were prepared in $25-\mu \mathrm{L}$ reactions containing PCR buffer $(1 \mathrm{x})$, (Invitrogen, NL) $\mathrm{MgCl}_{2}$ (3.0 mM), (Invitrogen, NL), dNTPs $(0.2 \mathrm{mM})$ (Promega, NL), forward and reverse primers $(0.4 \mu \mathrm{M}$; Supplementary Table 3), Taq polymerase (1.25 U) (Invitrogen, $\mathrm{NL})$, and $1 \mu \mathrm{L}$ of DNA. The PCR reactions were carried out in a T100 Thermal Cycler (BioRad), following similar denaturation conditions $\left(95^{\circ} \mathrm{C}\right.$ for $\left.30 \mathrm{~s}\right)$, but specific annealing and elongation conditions $\left(57,55\right.$, or $60^{\circ} \mathrm{C}$ for $30 \mathrm{~s}$; and $30-90 \mathrm{~s}$ at $72^{\circ} \mathrm{C}$ for the $16 \mathrm{~S}$ rRNA, gfpmut3, and mCherry genes, respectively), in 30 cycles. The specificity of the PCR products was confirmed by visualization in $1.5 \%$ agarose gel stained with ethidium bromide.

\section{Data Analysis}

One-way analysis of variance (ANOVA) was conducted to detect differences in the conjugation frequencies, between strains, temperatures, and culture media. The ANOVA tests were followed by TukeyHSD post hoc analysis, and homogeneity of variance was confirmed with Levene's test. Data normality was confirmed with Shapiro-Wilk's method, and when normality was not achieved, group comparison was performed using the equivalent non-parametric test (Kruskal-Wallis). A significance score of $p<0.05$ was considered to be statistically relevant. These analyses were performed with $\mathrm{R}$ version 3.5.1 ( $\mathrm{R}$ Core Team, 2018) and RStudio (Version 1.1.456 ${ }^{2}$ ). Used software packages consisted of reshape (Wickham, 2007) and tidyverse (Wickham et al., 2019), a set of packages designed for data cleaning, trimming, and visualization; of Rcmdr (Fox, 2005), PMCMRplus (Thorsten, 2020), and car (Fox and Weisberg, 2019) for ANOVA and Levene's test.

\section{RESULTS}

\section{Effect of Donor-to-Recipient (D/R) Ratios}

Before the temperature and nutrients assays, the $\mathrm{D} / \mathrm{R}$ ratios were tested to assess the limit of the system while aiming for a natural proportion of donor and recipient cells in the mating.

Under optimal conditions and $1: 1 \mathrm{D} / \mathrm{R}$ ratio $\left(37^{\circ} \mathrm{C}\right.$ and $\mathrm{LB}, 8.9 \times 10^{6} \mathrm{CFU} \mathrm{cm}^{-2}$ ), two out of three $E$. coli strains

\footnotetext{
${ }^{2} \mathrm{https} / /$ www.rstudio.com/
} 
(38.27 and 39.62) yielded high transconjugant numbers $\left(10^{9}\right.$ CFUs $\left.\mathrm{mL}^{-1}\right)$ and transfer frequency $\left(5 \times 10^{-1}\right)$ of IncP-1 plasmids. On the other hand, the mating with strain 09.54

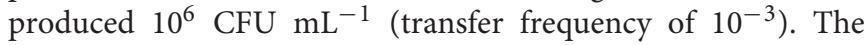
transfer frequency, measured as the transconjugants-to-donors ratio $(\mathrm{T} / \mathrm{D})$, resulted in a slight increase in the $1: 10$ and $1: 100 \mathrm{D} / \mathrm{R}$ proportions in comparison with the $1: 1$ proportion in all strains (except for one replicate of strain 09.54; Figure 2). Contrarily, the transconjugants-to-recipients ratio $(\mathrm{T} / \mathrm{R})$ decreased with the different $\mathrm{D} / \mathrm{R}$ ratios, approximately -0.7 logs and -1.8 logs in the $1: 10$ and $1: 100$ proportions, respectively (strains 38.27 and 39.62). A stronger effect of $D / R$ was observed for strain 09.54, where the T/R decreased 1-3 logs and 34 logs in the 1:10 and 1:100 proportion, respectively. Similar results were found for the absolute numbers of transconjugants (Figure 1 in Supplementary information). No transconjugants were recovered for one replicate in the mating of the strains
09.54 (1:100; Figure 1). At both 1:10 and 1:100 proportions, transconjugant numbers reached approximately $10^{3} \mathrm{CFUs}_{\mathrm{mL}}^{-1}$ for at least one of the replicates, which was close to the detection limit $\left(10^{2}\right.$ CFUs $\left.\mathrm{mL}^{-1}\right)$.

\section{Role of Temperature on Conjugative Transfer}

Conjugation efficiency among ESBL E. coli strains was assessed at temperatures ranging from the optimal laboratory $\left(37^{\circ} \mathrm{C}\right)$, room $\left(25^{\circ} \mathrm{C}\right)$ and relevant environmental $\left(15^{\circ} \mathrm{C}, 9^{\circ} \mathrm{C}\right)$ conditions.

Overall, lower temperatures significantly reduced the number of conjugation events ( $p<0.01$; Figure 3 ). Both T/D and $\mathrm{T} / \mathrm{R}$ decreased with decreasing temperatures, with a more pronounced reduction in strain 09.54 than in the other two strains (Figure 3). The highest number of transconjugants was obtained at $37^{\circ} \mathrm{C}$, and at $25^{\circ} \mathrm{C}$, and the number of

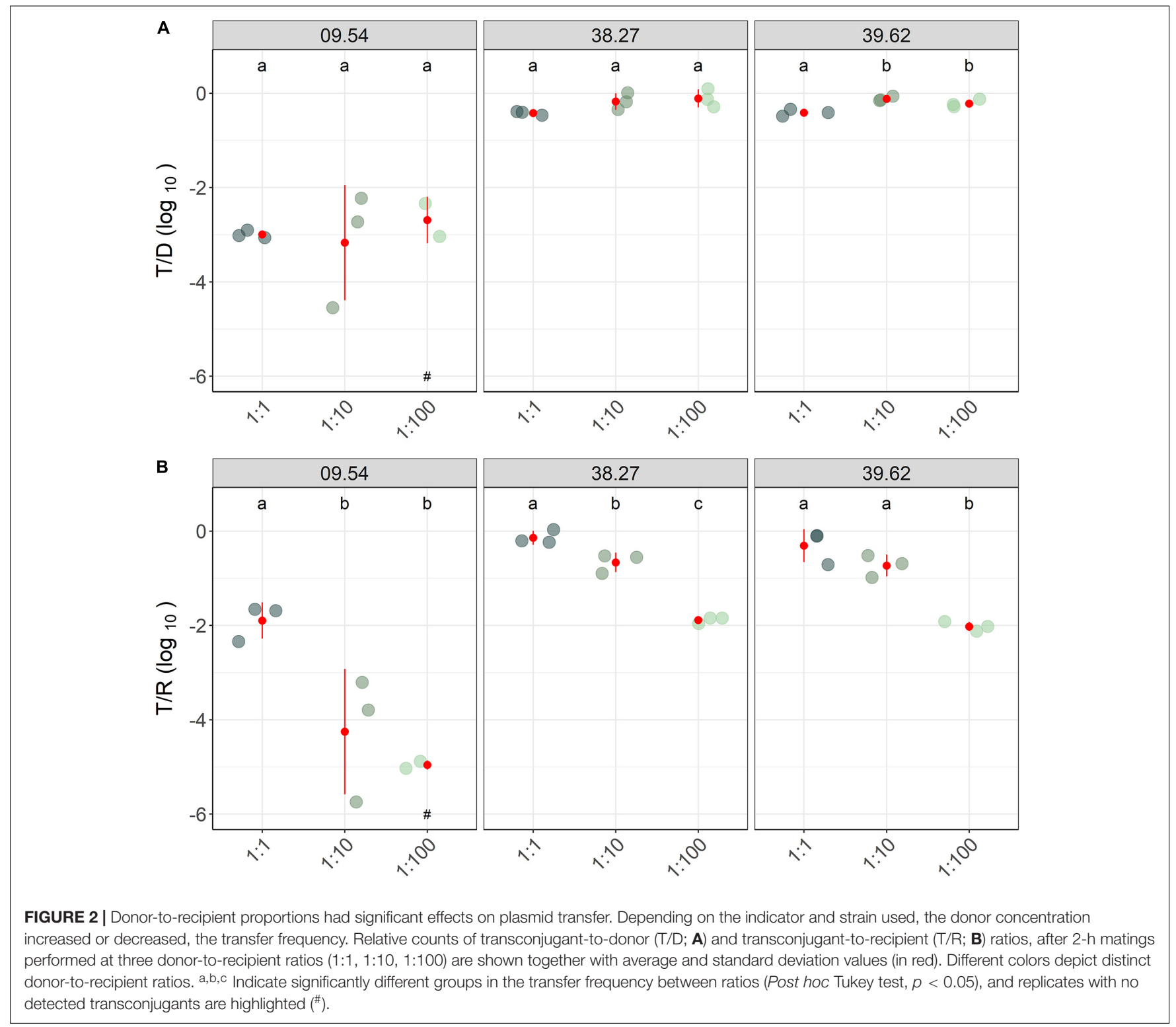


transconjugants decreased roughly 1 log (strains 38.27 and 39.62) or 2 logs (strain 09.54), depending on the strain. With further temperature reduction, lower transconjugant numbers were observed, and at $9^{\circ} \mathrm{C}$, conjugation still occurred in all tested strains.

The lowest number of transconjugants was obtained at $9^{\circ} \mathrm{C}$ for strains 38.27 and 39.62. In strain 09.54, the minimum transconjugant number was already reached at $15^{\circ} \mathrm{C}$ and maintained at $9^{\circ} \mathrm{C}$. However, higher variability among replicates was noticeable with strain 09.54 (Supplementary Figure 2), and one replicate did not yield detectable transconjugants (Supplementary Figure 2).

\section{Role of Nutrient Concentrations on Conjugative Transfer}

Differences in plasmid transfer under diverse nutrient regimes were assessed by comparing conjugation yields and transfer frequencies between rich nutrient media (LB) and common surrogates for natural conditions such as SWW and SE media.

In all tested strains, the decrease in the nutrient concentration of the media resulted in a substantial decrease in conjugation events (Figure 4). In comparison with the matings performed in LB, SWW resulted in the reduction of conjugation events by roughly 2 logs. In SE, a 4 -log reduction was observed for strain 39.62 (compared to LB; 4), but no transconjugants were recovered for other strains, despite several attempts.

The decline in transconjugant numbers was particularly severe for strain 09.54, which presented the lower number of transconjugants in LB. Its transconjugants were only recovered in one out of three matings performed in SWW, and when SE was used, a further decrease in the number of transconjugants was observed. While matings with strain 39.62 yielded $1.3 \times 10^{3}$ CFUs $\mathrm{mL}^{-1}$ transconjugants ( 3 and 6 logs lower than in SWW and LB, respectively; Supplementary Figure 3), the strains
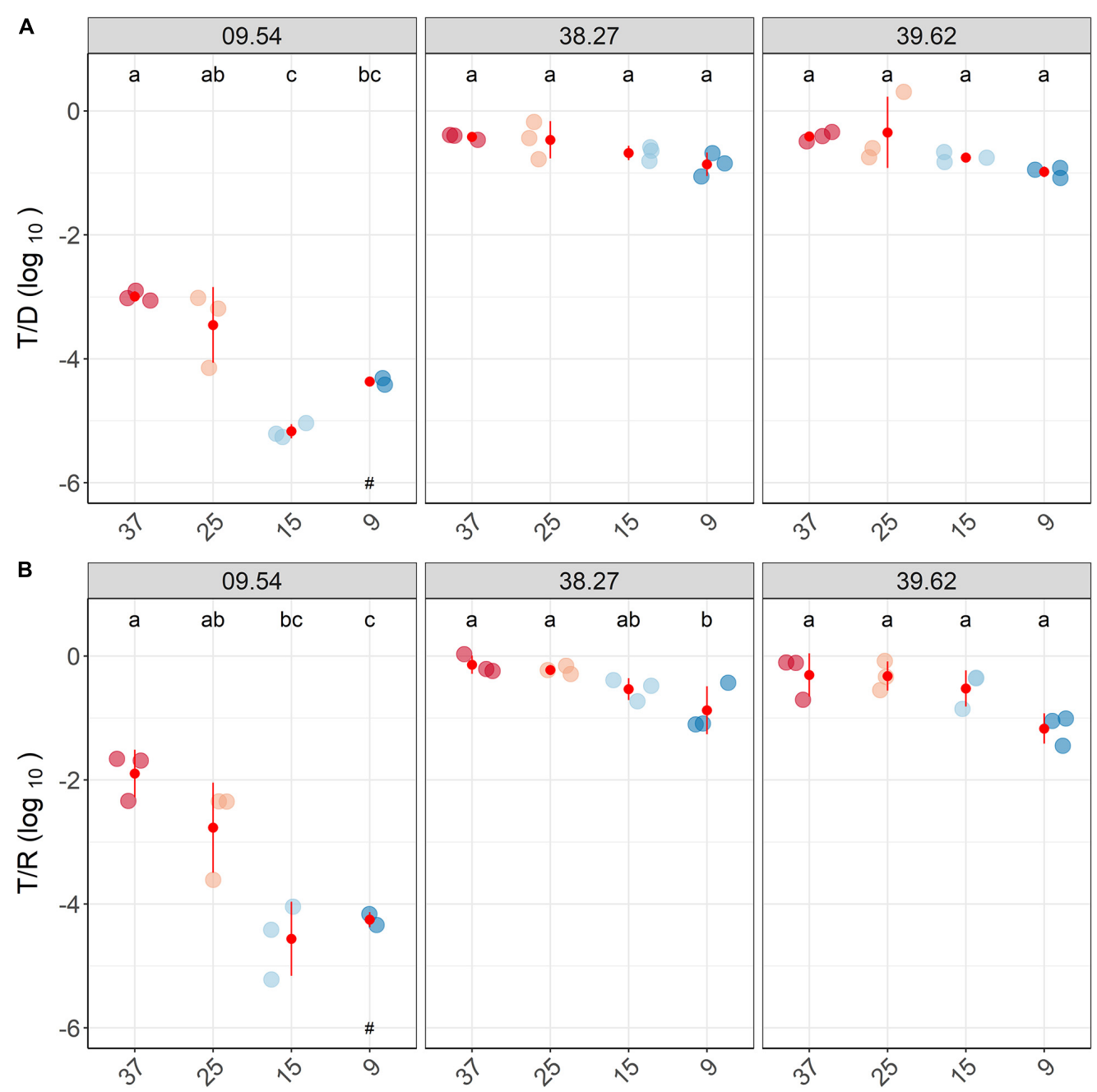

FIGURE 3 | Lower temperature reduced the number of conjugation events. Relative counts of transconjugant-to-donor (T/D; A) and transconjugant-to-recipient (T/R; B) after $2 \mathrm{~h}$-matings performed, at diverse temperatures $\left(37-9^{\circ} \mathrm{C}\right)$, are shown together with average and standard deviation values (in red). Different colors depict distinct temperatures. ${ }^{a, b, c}$ Indicate significantly different groups in the transfer frequency between temperatures (PostHoc Tukey test, $\left.p<0.05\right)$, and replicates with no detected transconjugants are highlighted (\#). 

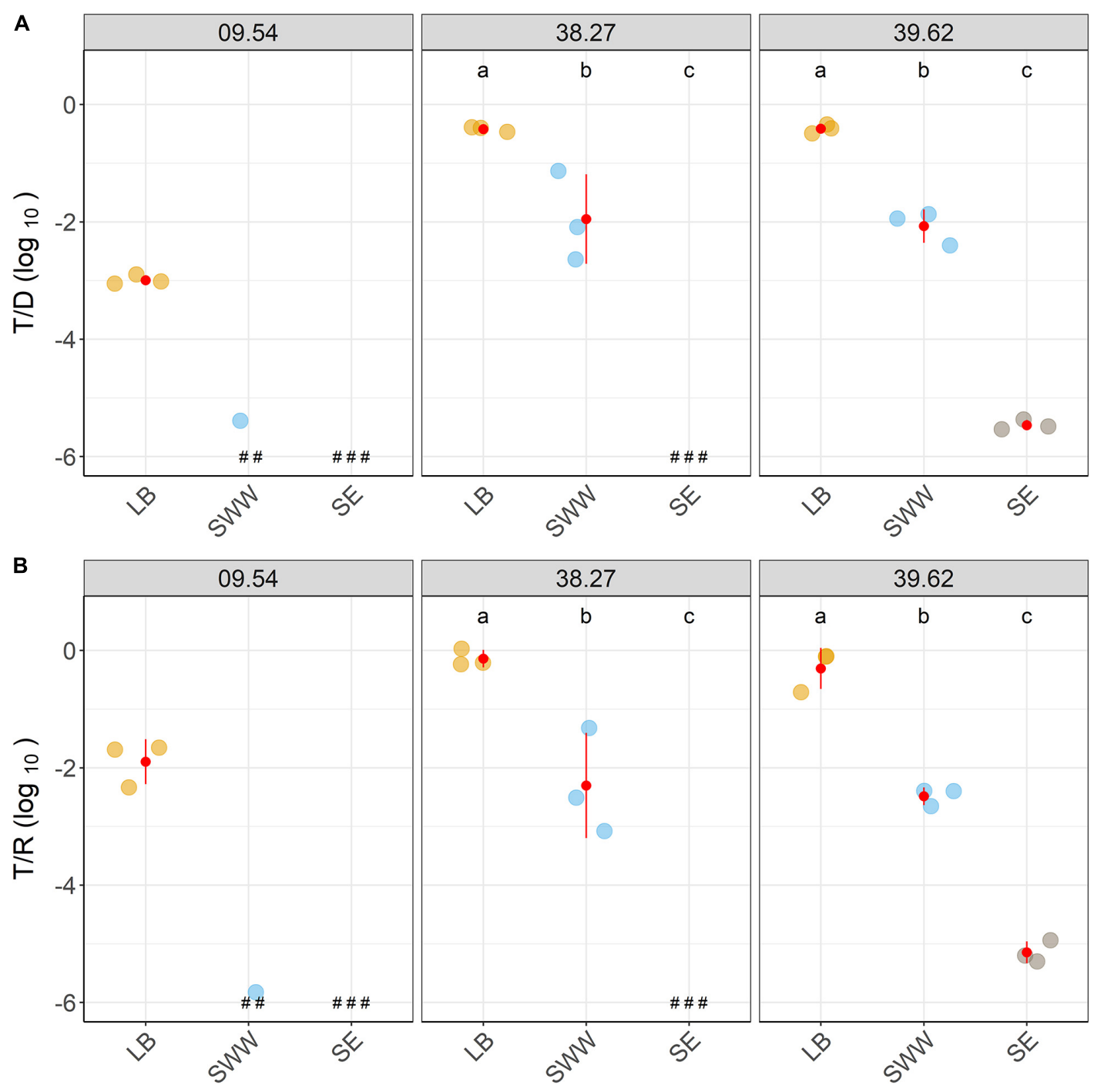

FIGURE 4 | Decrease in nutrient concentration reduced conjugation events. Relative counts of transconjugant-to-donor (T/D; A) and transconjugant-to-recipient (T/R; B) after 2h-matings performed, at diverse nutrient conditions (Luria-Bertani, LB; synthetic wastewater, SWW; and soil extract, SE), are shown together with average and standard deviation values (in red). Different colors depict distinct media. ${ }^{a, b, c}$ Indicate significantly different groups of transfer frequency between culture media (PostHoc Tukey test, $p<0.05$ ), and replicates with no detected transconjugants are highlighted $\left({ }^{\#}\right)$.

09.54 and 38.27 did not produce detectable transconjugants (Supplementary Figure 3).

\section{DISCUSSION}

The effects of temperature and nutrient abundance during mating of an IncP-1 plasmid were evaluated in three natural ESBL E. coli recipient strains by monitoring both total amounts of transconjugants and transfer frequencies. The results confirmed that psychrophilic temperatures during mating, as well as nutrient limitation, resulted in the reduction of transfer events. The decrease in the number of transconjugants was more prominent with lower nutrients than with lower temperatures.

\section{Transfer Efficiency Varied Across Strains}

Under optimal physiological conditions for the growth of the three E. coli strains $09.54,38.27$, and 39.62 tested (rich LB medium, higher mesophilic temperature of $37^{\circ} \mathrm{C}$ ), the conjugative transfer of plasmid significantly differed among the recipients. Two strains showed a high frequency of transfer $\left(5 \times 10^{-1}\right)$, while the third (strain 09.54) had 2 logs less. High frequency of transfer is common among IncP-1 plasmids (Thomas and Smith, 1987), which are naturally derepressed (Bradley et al., 1980). Similar transfer frequencies $\left(10^{-2}\right)$ have been described before for the pKJK5 plasmid in soil microcosms (Musovic et al., 2006). The difference of transfer frequency among strains from the same species can relate to strain-specific characteristics or repression of silencing systems that either 
avoid or limit the expression of the new acquire genes in the recipient cell (Frost and Koraimann, 2010). The plasmid stability and replication depend heavily on complex coordination and synchronicity between the vector and host (Novick, 1987). In the present study, only one bacterial species (E. coli) was used to minimize potential genetic incompatibilities between donor and recipients. However, even when the same species are used, variable transfer frequencies are often reported. For instance, Dimitriu et al. (2019) observed a difference up to 5 orders of magnitude in the transfer frequencies of an IncF and IncP-1 among naturally co-occurring $E$. coli isolates. These significant differences are likely linked to the genetic diversity within species. Here, the accessory genes in the used strains corresponded to roughly 50\% of the genomic content (Supplementary Figure 5). However, which of these accessory traits can be the cause of variation remains a matter of discussion. Dimitriu et al. (2019) found no preferential transfer among isolates sharing serotype or closely related phylogeny. Instead, they proposed that conjugal transfer was favored by clone-relationship, derived from similar restriction-modification systems. Contrarily, a recent study evaluating the transfer of ESBL plasmids among clinical E. coli isolates could not find such a relationship Benz et al. (2021).

In addition to host-recipient dynamics, plasmid to plasmid interactions could also affect the transfer dynamics. The stability of a newly acquired plasmid can be strongly influenced by the presence of other plasmids inside the cell (i.e., incompatibility). Here, we prevented the possible incompatibility issues by using strains with plasmids belonging to distinct Inc groups. Still, alternative effects of co-resident plasmids have been proposed recently. Enhanced transfer frequency of IncP-1 plasmids toward recipient cells hosting IncF plasmids has been observed (Gama et al., 2017). Although the mechanism of action is not entirely clear, the authors suggest that this is not a cooperative process but rather opportunistic use of the IncF transfer machinery by IncP-1 plasmids (Gama et al., 2017). In our experiments, we observed that the two strains with higher transfer frequency contained natural IncF plasmids (among others), whereas 09.54 harbored an IncK plasmid. However, further analysis would be necessary to confirm the role of co-existing plasmids in the recipient cell.

\section{Reducing Input of Donors Reduced Overall Transfer Frequency}

A lower $\mathrm{D} / \mathrm{R}$ proportion resulted in a decreased number of transconjugants, suggesting that the relative proportion of donors to recipients can limit HGT.

Receiving environmental compartments typically contain high cell densities, for instance, activated sludge usually contains between $10^{9}$ and $10^{10} \mathrm{CFU} \mathrm{mL}^{-1}$ (Manti et al., 2008) and topsoil (the first $10-15 \mathrm{~cm}$ ) contain between $10^{14}$ and $10^{15}$ cells $/ \mathrm{m}^{3}$ (Bickel and Or, 2020). However, exogenous bacteria that enter the system (potential donors) might not be as numerous. For example, assuming a soil density of 1.5 , it results in having $10^{8}-10^{9}$ cells/g soil, while the manure from cattle and pigs contains roughly $10^{5}$ E. coli cells/g (Schmitt et al., 2019), at least a 1,000 -fold difference. This means that the proportion of potential donors is quite small considering the receiving community. This proportion may depend on multiple factors, including sewage flows or manure application rates, but it is reasonable to expect that the potential donors will be a minority in the compartment to which they were introduced.

During conjugation assays, high cell densities $\left(8.9 \times 10^{6} \mathrm{CFU}\right.$ $\mathrm{cm}^{-2}$ ) would mirror natural systems. Conversely, the use of D/R ratios lower than 1:1 (i.e., 1:10 and 1:100) would presumably reflect more accurately the conditions found in anthropogenically impacted environments. However, to observe differences in conjugation rates under varied conditions, the number of donors should be sufficient to produce a detectable amount of transconjugants with a wide margin from the limit of detection (3 to 4 logs) in the matings performed under optimal conditions. Goodman et al. (1993) and Rochelle et al. (1989) observed that a minimum of $10^{4} \mathrm{CFU} \mathrm{cm} \mathrm{cm}^{-2}$ of donors and recipients were necessary to observe transconjugants. Here, conjugation

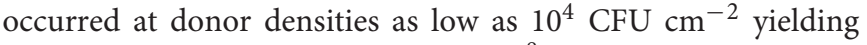
a high amount of transconjugants $\left(10^{8}\right)$ for two of the strains (38.27 and 39.62), but not for the third one (strain 09.54). For this last strain, transconjugants were undetectable or close to the limit of detection with initial donor densities of $10^{4}$ or $10^{5} \mathrm{CFU}$ $\mathrm{cm}^{-2}$ (D/R of 1:100 and 1:10, respectively). Considering that low $\mathrm{D} / \mathrm{R}$ could prevent the monitoring of conjugation events for at least one of the strains, the subsequent experiments were conducted with a $\mathrm{D} / \mathrm{R}$ ratio of $1: 1$. Similar cell densities and ratios have been previously advised to observe changes in conjugal transfer across a range of (presumably) unfavorable conditions (Fernandez-Astorga et al., 1992).

\section{Lower Temperature Inhibited Plasmid Transfer, but not Entirely}

The highest number of transconjugants was obtained at $37^{\circ} \mathrm{C}$, which is also the optimal growth temperature for E. coli. However, growth of donors and recipients was observed between their concentrations at the start of the experiment and in the controls (approximately $1 \mathrm{log}$, in all strains; Supplementary Figure 2). Together with growth curve data (data not shown), this suggests that, at $37^{\circ} \mathrm{C}$, part of the transconjugant numbers originated from clonal expansion rather than a new transfer event. Conversely, at other temperatures, the number of transconjugants observed reflected more accurately the real number of conjugation events, as the 2 -h mating time concurred with the lag phase, and, consequently, clonal expansion can assume to be negligible.

Fluctuations in temperature are known to greatly affect the growth and metabolic functions of microorganisms (Trevors et al., 2012). Yet, the effect of a wide range of temperatures on conjugative AMR-related plasmids has seldom been addressed (Bale et al., 1988; Inoue et al., 2005; Banerjee et al., 2016). Although cold conditions are predominantly found around the planet (Rodrigues and Tiedje, 2008) and in relevant environments for AMR spread (Supplementary Table 4), studies addressing the environmental dissemination of AMR plasmids in microcosms often used rather warm $\left(>25^{\circ} \mathrm{C}\right)$ settings. Warm temperatures $\left(25-30^{\circ} \mathrm{C}\right)$ are also common for in vitro studies that focus on either capturing environmental plasmids or addressing the 
microbial community permissiveness of a given plasmid, because high conjugation rates are required for detecting a high diversity of transconjugants (Jacquiod et al., 2017; Li et al., 2020, 2018).

Conjugation occurred at environmental temperatures (i.e., $15^{\circ} \mathrm{C}$ ), which are average temperatures found in wastewater and soil worldwide (Supplementary Table 4), but it also occurred at $9^{\circ} \mathrm{C}$. Typically, most wastewater treatment plants do not operate at temperatures below $9^{\circ} \mathrm{C}$ (because of nitrification failure), but in some countries, particularly northern countries, they can operate at temperatures close to $0^{\circ} \mathrm{C}$ (Delatolla et al., 2012; Hoang et al., 2014). The use of different strains emphasized that the effect of temperature on the transfer frequency is recipient-dependent and probably not affected just by chromosomally encoded factors, but also by resident plasmids in the recipient. The different outcomes observed between strains highlights the difficulty of inferring results that can be applicable to all putative recipient strains, even when they belong to the same species.

\section{Lower Nutrient Composition Hindered Conjugation}

A stronger effect on the transfer frequency was observed in matings performed with lower nutrient concentrations, where the frequency of conjugation was proportional to the nutrient richness of the culture media $(\mathrm{LB}>\mathrm{SWW}>\mathrm{SE}$ ). In some cases, it was not possible to recover transconjugants in SE. Some authors suggest that plasmid transfer is related to cell growth and does not occur in non-growing cells (Seoane et al., 2011; Kohyama and Suzuki, 2019), others consider that it happens after cell division and right before entering a non-growing phase (Headd and Bradford, 2020). We observed conjugation in SE media for at least one of the conjugation pairs, despite cell growth was not observed for either donor or recipients in this media.

Comparatively, the SE and SWW media used in this study contained 40 to 300 -fold (SE), and 20- to 40-fold (SWW) lower basic nutrients (carbon, nitrogen and phosphorus) concentrations than the classical nutrient-rich media (LB; Table 2). Conjugation requires energy and cellular resources to occur, and thus, one could expect that low nutrient conditions would hamper plasmid transfer (Goodman et al., 1993). Interestingly, the effect of nutrient deprivation on conjugation is seldom documented. Fernandez-Astorga et al. (1992) addressed the effect of available TOC in liquid media, finding transconjugants even at $1 \mathrm{mg} \mathrm{L}^{-1}$ of TOC. Inoue et al. (2005) observed decreasing transconjugants in media with a decreasing amount of dissolved organic carbon (DOC) (6'636 to $21.6 \mathrm{mg} \mathrm{L}^{-1}$ ), including $\mathrm{LB}$, synthetic, and real wastewater. However, in the two aforementioned studies and elsewhere (Grabow et al., 1975; O’Morchoe et al., 1988; MacDonald et al., 1992; Headd and Bradford, 2018), donor and recipient cells were pre-grown in a nutrient-rich media and then subjected to conjugation in the low nutrient media. Extra energy and nutrients stored in the cells during this pre-growth phase may allow bacteria to undergo conjugation in an earlier stage of the mating, potentially masking the effect of lower nutrition conditions on conjugation (Curtiss et al., 1969). To bypass this bias, Goodman et al. (1993) starved donors and recipients in minimal media (low amount of salts and no carbon source) prior to the conjugation. They found that, despite the lack of nutrients, conjugation occurred after the donors were starved up to 3 or 20 days, when E. coli or Vibrio sp. were the donors, respectively. In the current study, when addressing conjugal transfer in low nutrient media, cells were also pre-incubated in the corresponding low-nutrient media (SWW or SE) to avoid the influence of intracellular nutrient reservoirs.

Then again, carbon concentration is likely not the only nutrient that can limit conjugation. In their work, Inoue et al. (2005) observed that transconjugants and transfer rates were 2.5 logs higher in SWW than in 16-fold diluted LB, while both contained similar DOC content $\left(410 \mathrm{mg} \mathrm{L}^{-1}\right)$. Possibly, higher concentration of other nutrients (nitrogen, phosphorus or specific cations) in the SWW allowed an increase in conjugation frequencies and/or clonal expansion of the transconjugants. Pregrowth in media lacking casamino acids delayed pili formation after nutritional conditions are restored (Curtiss et al., 1969). As pili formation is protein-dependent, nitrogen-compounds are required for plasmid transfer. Despite being an essential nutrient, the role of phosphate or inorganic phosphorus deprivation in conjugation has not been explored yet. Phosphorus is known to be a limiting factor of cell growth and metabolism in oligotrophic environments (Smith and Prairie, 2004). In E. coli, phosphorus starvation induces a wide range of metabolic changes including cell surface modification and increase of cell adhesion characteristics (adhesins and fimbria), which could affect the interaction between cells and ultimately the conjugation rates. Finally, the concentration of other micronutrients as divalent cations might also influence conjugation. Recently, Sakuda et al. (2018) observed that the addition of divalent cations to low nutrient media $\left(\mathrm{Ca}^{2+}\right.$ and $\mathrm{Mg}^{2+}$ ) increased the conjugation frequency of IncP-7 plasmids among Pseudomonas strains. Yet, the molecular mechanisms of this effect remain unclear.

Moreover, in the present study, the $\mathrm{pH}$ values of the different media were not maintained or adjusted, except in SWW. In SWW, the $\mathrm{pH}$ was adjusted to 6.8 close to the ones observed in wastewater [6.5-8.5 (Prot et al., 2020)] while the $\mathrm{pH}$ from SE was kept at its original value $(5.0-5.3)$, which was representative of Dutch soils of this texture (Römkens and Oenema, 2004). Soil was kept at ambient $\mathrm{pH}$ to maintain solubility of soil nutrients. As $\mathrm{pH}$ can affect bacterial growth, it could have also contributed to the decrease of transconjugants in this study observed for soil. Indeed, it has been shown that $\mathrm{pH}$ values in this range (5.0 5.3) can decrease conjugation (Richaume et al., 1989), but it only resulted in a maximum of 3 -fold reduction ( 0.5 logs) when compared to conjugation occurring at neutral $\mathrm{pH}$. In the context of the present study, it is difficult to discriminate what was the effective contribution of $\mathrm{pH}$ in decreasing plasmid transfer in SE. However, given the several log decrease in transconjugants, it is reasonable to say that the lower nutrient content had a more important contribution in SE.

\section{Extrapolation of the Results and Limitations of the Study}

This study addresses the influence of temperature and nutrient conditions on a specific system based on E. coli strains and an IncP-1 broad-host range plasmid. Probably, the impact of 
the factors addressed here would differ per species. Bacteria better suited to thrive under typical environmental conditions will most likely be less affected by low temperatures and nutrient conditions, as observed by a longer ability ( +13 days) for conjugal transfer when using pre-starved Vibrio spp. as donor instead of E. coli (Goodman et al., 1993). In addition, the plasmid characteristics (e.g., size, incompatibility group) obviously determine absolute transfer rates. Thus, further research addressing other combinations of donors-recipients will be desirable.

\section{CONCLUSION}

When moving from laboratory conditions to environmentally relevant conditions for soils and WWTPs, both lower temperature and lower nutrient concentrations showed to reduce conjugal transfer of an IncP-1 plasmid significantly. The effect lower nutrient concentrations on the number of transconjugants was stronger than the effect of lower temperatures. While nutritional conditions appear critical, the role of single nutrients, such as nitrogen and phosphorus, is not entirely clear and deserves further follow-up research. Furthermore, the transfer potential was recipient-dependent and varied within ESBL E. coli strains of the same species.

To conclude, although abiotic factors can hamper plasmid transfer, measurable conjugation between E. coli still occurred under conditions that mimicked those commonly found in the wastewater and soil environment $\left(9-25^{\circ} \mathrm{C}\right)$. Despite conjugation being observed between strains of the same species, this study shows that fecal indicator bacteria were capable of donating an IncP-1 plasmid in less-than-optimal contexts, and consequently, can be a source of transferable AMR traits once they reach the environment.

\section{DATA AVAILABILITY STATEMENT}

The datasets presented in this study can be found in online repositories. The names of the repository/repositories and accession number(s) can be found in the article/ supplementary material.

\section{REFERENCES}

Abis, K. L., and Mara, D. (2006). Temperature measurement and stratification in facultative waste stabilisation ponds in the UK climate. Environ. Monit. Assess. 114, 35-47. doi: 10.1007/s10661-006-1076-7

Al Qarni, H., Collier, P., O’Keeffe, J., and Akunna, J. (2016). Investigating the removal of some pharmaceutical compounds in hospital wastewater treatment plants operating in Saudi Arabia. Environ. Sci. Pollut. Res. 23, 13003-13014. doi: 10.1007/s11356-016-6389-7

Amann, R. I., Ludwig, W., and Schleifer, K.-H. (1995). Phylogenetic identification and in situ detection of individual microbial cells without cultivation. Microbiol. Mol. Biol. Rev. 59, 143-169. doi: 10.1128/mmbr.59.1.143-169. 1995

Bahl, M. I., Hansen, L. H., and Sørensen, S. J. (2007). Impact of conjugal transfer on the stability of IncP-1 plasmid pKJK5 in bacterial populations. FEMS Microbiol. Lett. 266, 250-256. doi: 10.1111/j.1574-6968.2006.00536.x

\section{AUTHOR CONTRIBUTIONS}

RP-V, GM, LH, and HS conceived and designed the study. RP-V and GM performed the experiments and analyzed the data. $\mathrm{MB}$ and RP-V performed the analysis of the next-generation sequencing data. MB, LH, DM, DH, ML, DW, and HS supervised the study. RP-V and GM wrote the manuscript. MB, LH, PM, ML, DW, DM, DH, and HS reviewed and edited the manuscript. All authors read and approved the final manuscript.

\section{FUNDING}

This work was performed in the cooperation framework of Wetsus, European Centre of excellence for sustainable water technology (www.wetsus.nl). Wetsus is co-funded by the Dutch Ministry of Economic Affairs and Ministry of Infrastructure and Environment, the European Union Regional Development Fund, the Province of Frysl`an and the Northern Netherlands Provinces. This work has also received funding from STOWA and from the European Union's Horizon 2020 Research and Innovation Program under the Marie Skłodowska-Curie [grant agreement no. 665874]. The authors like to thank the participants of the Wetsus research theme Source Separated Sanitation for the fruitful discussions and their financial support.

\section{ACKNOWLEDGMENTS}

We gratefully acknowledge the support of the former students Xavier Gallego y van Seijen, Hana Piková, Gonzalo Monteoliva, Wesley Klaassen, Amaya Gómez, Dimitrios Maroulis, and Jenneke van der Draai for their relentless technical assistance in performing the conjugation assays. We extend our gratitude to professor Søren J. Sørensen for kindly donating the donor strain.

\section{SUPPLEMENTARY MATERIAL}

The Supplementary Material for this article can be found online at: https://www.frontiersin.org/articles/10.3389/fmicb. 2021.656250/full\#supplementary-material

Bale, M. J., Fry, J. C., and Day, M. J. (1988). Transfer and occurrence of large mercury resistance plasmids in river epilithon. Appl. Environ. Microbiol. 54, 972-978. doi: 10.1128/aem.54.4.972-978.1988

Banerjee, G., Ray, A. K., and Kumar, R. (2016). Effect of temperature on lateral gene transfer efficiency of multi-antibiotics resistant bacterium, alcaligenes faecalis. Sains Malays. 45, 909-914.

Barrios-Hernández, M. L., Pronk, M., Garcia, H., Boersma, A., Brdjanovic, D., van Loosdrecht, M. C. M., et al. (2020). Removal of bacterial and viral indicator organisms in full-scale aerobic granular sludge and conventional activated sludge systems. Water Res. 6:40. doi: 10.1016/j.wroa.2019.100040

Bellanger, X., Guilloteau, H., Bonot, S., and Merlin, C. (2014a). Demonstrating plasmid-based horizontal gene transfer in complex environmental matrices: a practical approach for a critical review. Sci. Total Environ. 493, 872-882. doi: 10.1016/j.scitotenv.2014.06.070

Bellanger, X., Guilloteau, H., Breuil, B., and Merlin, C. (2014b). Natural microbial communities supporting the transfer of the IncP- $1 \beta$ plasmid pB10 exhibit a 
higher initial content of plasmids from the same incompatibility group. Front. Microbiol. 5:637. doi: 10.3389/fmicb.2014.00637

Benz, F., Huisman, J. S., Bakkeren, E., Herter, J. A., Stadler, T., Ackermann, M., et al. (2021). Plasmid- and strain-specific factors drive variation in ESBL-plasmid spread in vitro and in vivo. ISME J. 15, 862-878. doi: 10.1038/s41396-02000819-4

Bickel, S., and Or, D. (2020). Soil bacterial diversity mediated by microscale aqueous-phase processes across biomes. Nat. Commun. 11:116. doi: 10.1038/ s41467-019-13966-w

Binh, C. T. T., Heuer, H., Kaupenjohann, M., and Smalla, K. (2008). Piggery manure used for soil fertilization is a reservoir for transferable antibiotic resistance plasmids. FEMS Microbiol. Ecol. 66, 25-37. doi: 10.1111/j.1574-6941. 2008.00526.x

Boeije, G., Corstanje, R., Rottiers, A., and Schowanek, D. (1999). Adaptation of the CAS test system and synthetic sewage for biological nutrient removal. Chemosphere 38, 699-709. doi: 10.1016/S0045-6535(98)00311-7

Bradley, D. E., Taylor, D. E., and Cohen, D. R. (1980). Specification of surface mating systems among conjugative drug resistance plasmids in Escherichia coli K-12. J. Bacteriol. 143, 1466-1470. doi: 10.1128/jb.143.3.1466-1470.1980

Carattoli, A. (2013). Plasmids and the spread of resistance. Int. J. Med. Microbiol. 303, 298-304. doi: 10.1016/j.ijmm.2013.02.001

Carattoli, A., Zankari, E., Garciá-Fernández, A., Larsen, M. V., Lund, O., Villa, L., et al. (2014). In Silico detection and typing of plasmids using plasmidfinder and plasmid multilocus sequence typing. Antimicrob. Agents Chemother. 58, 3895-3903. doi: 10.1128/AAC.02412-14

Ceccarelli, D., Kant, A., Van Essen-Zandbergen, A., Dierikx, C., Hordijk, J., Wit, B., et al. (2019). Diversity of plasmids and genes encoding resistance to extended spectrum cephalosporins in commensal Escherichia coli From Dutch livestock in 2007-2017. Front. Microbiol. 10:76. doi: 10.3389/fmicb.2019.00076

Curtiss, R., Caro, L. G., Allison, D. P., and Stallions, D. R. (1969). Early stages of conjugation in Escherichia coli. J. Bacteriol. 100, 1091-1104. doi: 10.1128/JB.100. 2.1091-1104.1969

Delatolla, R., Tufenkji, N., Comeau, Y., Gadbois, A., Lamarre, D., and Berk, D. (2012). Effects of long exposure to low temperatures on nitrifying biofilm and biomass in wastewater treatment. Water Environ. Res. 84, 328-338. doi: $10.2175 / 106143012 \times 13354606450924$

Dimitriu, T., Marchant, L., Buckling, A., and Raymond, B. (2019). Bacteria from natural populations transfer plasmids mostly towards their kin. Proc. R. Soc. B Biol. Sci. 286:20191110. doi: 10.1098/rspb.2019.1110

Fan, X.-T., Li, H., Chen, Q.-L., Zhang, Y.-S., Ye, J., Zhu, Y.-G., et al. (2019). Fate of antibiotic resistant Pseudomonas putida and broad host range plasmid in natural soil microcosms. Front. Microbiol. 10:194. doi: 10.3389/fmicb.2019. 00194

Fernandez-Astorga, A., Muela, A., Cisterna, R., Iriberri, J., and Barcina, I. (1992). Biotic and abiotic factors affecting plasmid transfer in Escherichia coli strains. Appl. Environ. Microbiol. 58:2708. doi: 10.1128/aem.58.8.2708-2708.1992

Fox, J. (2005). The R commander: a basic statistics graphical user interface to $\mathrm{R}$. J. Stat. Softw. 14, 1-42.

Fox, J., and Weisberg, S. (2019). An R Companion to Applied Regression, 3 Edn. Thousand Oaks CA: Sage.

Frost, L. S., and Koraimann, G. (2010). Regulation of bacterial conjugation: balancing opportunity with adversity. Future Microbiol. 5, 1057-1071. doi: 10 . 2217/fmb.10.70

Gama, J. A., Zilhão, R., and Dionisio, F. (2017). Conjugation efficiency depends on intra and intercellular interactions between distinct plasmids: plasmids promote the immigration of other plasmids but repress co-colonizing plasmids. Plasmid 93, 6-16. doi: 10.1016/j.plasmid.2017.08.003

Goodman, A. E., Hild, E., Marshall, K. C., and Hermansson, M. (1993). Conjugative plasmid transfer between bacteria under simulated marine oligotrophic conditions. Appl. Environ. Microbiol. 59, 1035-1040. doi: 10.1128/aem.59.4. 1035-1040.1993

Grabow, W. O. K., Prozesky, O. W., and Burger, J. S. (1975). Behaviour in a river and dam of coliform bacteria with transferable or non-transferable drug resistance. Water Res. 9, 777-782. doi: 10.1016/0043-1354(75)90134-7

Hadfield, J., Croucher, N. J., Goater, R. J., Abudahab, K., Aanensen, D. M., and Harris, S. R. (2018). Phandango: an interactive viewer for bacterial population genomics. Bioinformatics 34, 292-293. doi: 10.1093/bioinformatics/ btx610
Headd, B., and Bradford, S. A. (2018). Physicochemical factors that favor conjugation of an antibiotic resistant plasmid in non-growing bacterial cultures in the absence and presence of antibiotics. Front. Microbiol. 9:2122. doi: 10. 3389/fmicb.2018.02122

Headd, B., and Bradford, S. A. (2020). The conjugation window in an Escherichia coli K-12 strain with an IncFII plasmid. Appl. Environ. Microbiol. 86, 1-18. doi: 10.1128/AEM.00948-20

Hoang, V., Delatolla, R., Abujamel, T., Mottawea, W., Gadbois, A., Laflamme, E., et al. (2014). Nitrifying moving bed biofilm reactor (MBBR) biofilm and biomass response to long term exposure to $1^{\circ} \mathrm{C}$. Water Res. 49, 215-224. doi: 10.1016/j.watres.2013.11.018

Hu, Y., Yang, X., Qin, J., Lu, N., Cheng, G., Wu, N., et al. (2013). Metagenome-wide analysis of antibiotic resistance genes in a large cohort of human gut microbiota. Nat. Commun. 4:2151. doi: 10.1038/ncomms 3151

Inoue, D., Sei, K., Soda, S., Ike, M., and Fujita, M. (2005). Potential of predominant activated sludge bacteria as recipients in conjugative plasmid transfer. J. Biosci. Bioeng. 100, 600-605. doi: 10.1263/jbb.100.600

Jacquiod, S., Brejnrod, A., Morberg, S. M., Abu Al-Soud, W., Sørensen, S. J., and Riber, L. (2017). Deciphering conjugative plasmid permissiveness in wastewater microbiomes. Mol. Ecol. 26, 3556-3571. doi: 10.1111/mec.14138

Jaureguy, F., Landraud, L., Passet, V., Diancourt, L., Frapy, E., Guigon, G., et al. (2008). Phylogenetic and genomic diversity of human bacteremic Escherichia coli strains. BMC Genom. 9:560. doi: 10.1186/1471-21649-560

Klümper, U., Riber, L., Dechesne, A., Sannazzarro, A., Hansen, L. H., Sørensen, S. J., et al. (2015). Broad host range plasmids can invade an unexpectedly diverse fraction of a soil bacterial community. ISME J. 9, 934-945. doi: 10.1038/ismej. 2014.191

Kohyama, Y., and Suzuki, S. (2019). Conjugative gene transfer between nourished and starved cells of Photobacterium damselae ssp. damselae and Escherichia coli. Microb. Environ. 34, 388-392. doi: 10.1264/jsme2.ME19099

Larsen, M. V., Cosentino, S., Rasmussen, S., Friis, C., Hasman, H., Marvig, R. L., et al. (2012). Multilocus sequence typing of total-genome-sequenced bacteria. J. Clin. Microbiol. 50, 1355-1361. doi: 10.1128/JCM.06094-11

Li, L., Dechesne, A., He, Z., Madsen, J. S., Nesme, J., Sørensen, S. J., et al. (2018). Estimating the transfer range of plasmids encoding antimicrobial resistance in a wastewater treatment plant microbial community. Environ. Sci. Technol. Lett. 5, 260-265. doi: 10.1021/acs.estlett.8b00105

Li, L., Dechesne, A., Madsen, J. S., Nesme, J., Sørensen, S. J., and Smets, B. F. (2020). Plasmids persist in a microbial community by providing fitness benefit to multiple phylotypes. ISME J. 14, 1170-1181. doi: $10.1038 /$ s41396-0200596-4

MacDonald, J. A., Smets, B. F., and Rittmann, B. E. (1992). The effects of energy availability on the conjugative-transfer kinetics of plasmid RP4. Water Res. 26, 461-468. doi: 10.1016/0043-1354(92)90046-7

Manti, A., Boi, P., Falcioni, T., Canonico, B., Ventura, A., Sisti, D., et al. (2008). Bacterial cell monitoring in wastewater treatment plants by flow cytometry. Water Environ. Res. 80, 346-354. doi: 10.2175/106143007×221418

Musovic, S., Dechesne, A., Sørensen, J., and Smets, B. F. (2010). Novel assay to assess permissiveness of a soil microbial community toward receipt of mobile genetic elements. Appl. Environ. Microbiol. 76, 4813-4818. doi: 10.1128/AEM. 02713-09

Musovic, S., Oregaard, G., Kroer, N., and Sørensen, S. J. (2006). Cultivationindependent examination of horizontal transfer and host range of an IncP-1 plasmid among gram-positive and gram-negative bacteria indigenous to the barley rhizosphere. Appl. Environ. Microbiol. 72, 6687-6692. doi: 10.1128/AEM. 00013-06

Novick, R. P. (1987). Plasmid incompatibility. Microbiol. Rev. 51, 381-395.

Ochman, H., Lawrence, J. G., and Groisman, E. A. (2000). Lateral gene transfer and the nature of bacterial innovation. Nature 405, 299-304. doi: 10.1038/35012500

O'Morchoe, S. B., Ogunseitan, O., Sayler, G. S., and Miller, R. V. (1988). Conjugal transfer of R68.45 and FP5 between Pseudomonas aeruginosa strains in a freshwater environment. Appl. Environ. Microbiol. 54, 1923-1929. doi: 10.1128/ AEM.54.8.1923-1929.1988

Osińska, A., Korzeniewska, E., Harnisz, M., Felis, E., Bajkacz, S., Jachimowicz, P., et al. (2020). Small-scale wastewater treatment plants as a source of the dissemination of antibiotic resistance genes in the aquatic environment. J. Hazard. Mater. 381:121221. doi: 10.1016/j.jhazmat.2019.121221 
O’Neill, J. (2016). Tackling drug-resistant infections globally: final report and recommendations. Lancet Infect. Dis. 16, 767-768.

Page, A. J., Cummins, C. A., Hunt, M., Wong, V. K., Reuter, S., Holden, M. T. G., et al. (2015). Roary: rapid large-scale prokaryote pan genome analysis. Bioinformatics 31, 3691-3693. doi: 10.1093/bioinformatics/btv421

Pallares-Vega, R., Hernandez Leal, L., Fletcher, B. N., Vias-Torres, E., van Loosdrecht, M. C. M., Weissbrodt, D. G., et al. (2021). Annual dynamics of antimicrobials and resistance determinants in flocculent and aerobic granular sludge treatment systems. Water Res. 190:116752. doi: 10.1016/j.watres.2020. 116752

Pinilla-Redondo, R., Cyriaque, V., Jacquiod, S., Sørensen, S. J., and Riber, L. (2018). Monitoring plasmid-mediated horizontal gene transfer in microbiomes: recent advances and future perspectives. Plasmid 99, 56-67. doi: 10.1016/j.plasmid. 2018.08.002

Popowska, M., and Krawczyk-Balska, A. (2013). Broad-host-range IncP-1 plasmids and their resistance potential. Front. Microbiol. 4:44. doi: 10.3389/fmicb.2013. 00044

Price, M. N., Dehal, P. S., and Arkin, A. P. (2010). FastTree 2 - approximately maximum-likelihood trees for large alignments. PLoS One 5:e09490. doi: 10. 1371/journal.pone.0009490

Prot, T., Korving, L., and van Loosdrecht, M. C. (2020). Ionic strength of the liquid phase of different sludge streams in a wastewater treatment plant. Chem. Rxiv [Preprint]. doi: 10.26434/chemrxiv.13359437.v1

R Core Team (2018). R: A Language and Environment for Statistical Computing. Vienna: R Found. Stat. Comput.

Richaume, A., Angle, J. S., and Sadowsky, M. J. (1989). Influence of soil variables on in situ plasmid transfer from Escherichia coli to Rhizobium fredii. Appl. Environ. Microbiol. 55, 1730-1734. doi: 10.1128/aem.55.7.1730-1734.1989 doi: 10.1128/aem.55.7.1730-1734.1989

Rochelle, P. A., Fry, J. C., and Day, M. J. (1989). Factors affecting conjugal transfer of plasmids encoding mercury resistance from pure cultures and mixed natural suspensions of epilithic bacteria. J. Gen. Microbiol. 135, 409-424. doi: 10.1099/ 00221287-135-2-409

Römkens, P. F. A. M., and Oenema, O. (2004). Quick Scan Soils in The Netherlands. Overview of the Soil Status With Reference to the Forthcoming EU Soil Strategy. Wageningen, Alterra, Alterra-Rapport 948. Wageningen: Alterra.

Rodrigues, D. F., and Tiedje, J. M. (2008). Coping with our cold planet. Appl. Environ. Microbiol. 74, 1677-1686. doi: 10.1128/AEM.02000-07

Rozwandowicz, M., Brouwer, M. S. M., Fischer, J., Wagenaar, J. A., Gonzalez-Zorn, B., Guerra, B., et al. (2018). Plasmids carrying antimicrobial resistance genes in Enterobacteriaceae. J. Antimicrob. Chemother. 73, 1121-1137. doi: 10.1093/jac/ $\mathrm{dkx} 488$

Rozwandowicz, M., Hordijk, J., Bossers, A., Zomer, A. L., Wagenaar, J. A., Mevius, D. J., et al. (2020). Incompatibility and phylogenetic relationship of I-complex plasmids. Plasmid 109:102502. doi: 10.1016/j.plasmid.2020.102502

Sakuda, A., Suzuki-Minakuchi, C., Matsui, K., Takahashi, Y., Okada, K., Yamane, H., et al. (2018). Divalent cations increase the conjugation efficiency of the incompatibility P-7 group plasmid pCAR1 among different pseudomonas hosts. Microbiology 164, 20-27. doi: 10.1099/mic.0.000583

Schmitt, H., Blaak, H., Hoeksma, P., van de Schans, M., Kemper, M., de Rijk, S., et al. (2019). Antibioticaresistente Bacteriën, Resistentiegenen en Antibioticaresiduen in Mest. RIVM. doi: 10.21945/RIVM-2019-0112

Scott, K. P., Mercer, D. K., Glover, L. A., and Flint, H. J. (2006). The green fluorescent protein as a visible marker for lactic acid bacteria in complex ecosystems. FEMS Microbiol. Ecol. 26, 219-230. doi: 10.1111/j.1574-6941.1998. tb00507.x
Seemann, T. (2014). Prokka: rapid prokaryotic genome annotation. Bioinformatics 30, 2068-2069. doi: 10.1093/bioinformatics/btu153

Sengeløv, G., Kristensen, K. J., Sørensen, A. H., Kroer, N., and Sørensen, S. J. (2001). Effect of genomic location on horizontal transfer of a recombinant gene cassette between Pseudomonas strains in the Rhizosphere and Spermosphere of barley seedlings. Curr. Microbiol. 42, 160-167. doi: 10.1007/s002840010197

Seoane, J., Yankelevich, T., Dechesne, A., Merkey, B., Sternberg, C., and Smets, B. F. (2011). An individual-based approach to explain plasmid invasion in bacterial populations. FEMS Microbiol. Ecol. 75, 17-27. doi: 10.1111/j.1574-6941.2010. 00994.x

Shintani, M., Nour, E., Elsayed, T., Blau, K., Wall, I., Jechalke, S., et al. (2020). Plant species-dependent increased abundance and diversity of IncP-1 plasmids in the rhizosphere: new insights into their role and ecology. Front. Microbiol. 11:590776. doi: 10.3389/fmicb.2020.590776

Smillie, C., Garcillán-Barcia, M. P., Francia, M. V., Rocha, E. P. C., and de la Cruz, F. (2010). Mobility of plasmids. Microbiol. Mol. Biol. Rev. 74, 434-452. doi: 10.1128/MMBR.00020-10

Smith, E. M., and Prairie, Y. T. (2004). Bacterial metabolism and growth efficiency in lakes: the importance of phosphorus availability. Limnol. Oceanogr. 49, 137-147. doi: 10.4319/lo.2004.49.1.0137

Sørensen, S. J., Bailey, M., Hansen, L. H., Kroer, N., and Wuertz, S. (2005). Studying plasmid horizontal transfer in situ: a critical review. Nat. Rev. Microbiol. 3, 700-710. doi: 10.1038/nrmicro1232

Thomas, C. M., and Smith, C. A. (1987). Incompatibility group P plasmids: genetics, evolution, and use in genetic manipulation. Annu. Rev. Microbiol. 41, 77-101. doi: 10.1146/annurev.mi.41.100187.000453

Thorsten, T. (2020). PMCMRplus: Calculate Pairwise Multiple Comparisons of Mean Rank Sums Extended.

Trevors, J. T., Bej, A. K., Mojib, N., van Elsas, J. D., and van Overbeek, L. (2012). Bacterial gene expression at low temperatures. Extremophiles 16, 167-176. doi: 10.1007/s00792-011-0423-y

Wirth, T., Falush, D., Lan, R., Colles, F., Mensa, P., Wieler, L. H., et al. (2006). Sex and virulence in Escherichia coli: an evolutionary perspective. Mol. Microbiol. 60, 1136-1151. doi: 10.1111/j.1365-2958.2006. 05172.x

Wickham, H. (2007). Reshaping data with the reshape package. J. Stat. Softw. 21, 1-20. doi: 10.18637/jss.v021.i12

Wickham, H., Averick, M., Bryan, J., Chang, W., McGowan, L., François, R., et al. (2019). Welcome to the tidyverse. J. Open Source Softw. 4:1686. doi: 10.21105/ joss.01686

Zhong, X., Krol, J. E., Top, E. M., and Krone, S. M. (2010). Accounting for mating pair formation in plasmid population dynamics. J. Theor. Biol. 262, 711-719. doi: 10.1016/j.jtbi.2009.10.013

Conflict of Interest: The authors declare that the research was conducted in the absence of any commercial or financial relationships that could be construed as a potential conflict of interest.

Copyright (c) 2021 Pallares-Vega, Macedo, Brouwer, Hernandez Leal, van der Maas, van Loosdrecht, Weissbrodt, Heederik, Mevius and Schmitt. This is an open-access article distributed under the terms of the Creative Commons Attribution License (CC BY). The use, distribution or reproduction in other forums is permitted, provided the original author(s) and the copyright owner(s) are credited and that the original publication in this journal is cited, in accordance with accepted academic practice. No use, distribution or reproduction is permitted which does not comply with these terms. 